\title{
Pelatihan Pembuatan Minuman Serbuk Sari Buah untuk Meningkatkan Pengetahuan dan Ketrampilan Masyarakat
}

\author{
Fruit Juice Powder Drink Training To Increase Community Knowledge And Skill \\ ${ }^{1 *}$ Ridawati, ${ }^{2}$ Alsuhendra \\ 1,2,)Program Studi Pendidikan Tata Boga, Fakultas Teknik \\ Universitas Negeri Jakarta \\ Jalan Rawamangun Muka, Gedung H Lantai 3, Rawamangun Jakarta Timur 13220 \\ *email: ridawati.sesil@gmail.com
}

DOI:

10.30595/jppm.v5i1.9038

Histori Artikel:

Diajukan:

$17 / 11 / 2020$

Diterima:

$10 / 01 / 2022$

Diterbitkan:

$18 / 02 / 2022$

\section{ABSTRAK}

Masa pandemi Covid-19 secara umum menurunkan pendapatan masyarakat. Kegiatan pengabdian kepada masyarakat ini bertujuan untuk meningkatkan pengetahuan dan keterampilan masyarakat Keluarahan Benda Baru, Kecamatan Pamulang, Tangerang Selatan dalam mengolah sari buah menjadi minuman serbuk dalam kemasan. Buah-buahan merupakan salah satu hasil tanaman yang mudah diperoleh dan memiliki harga yang sangat murah saat panen. Kegiatan ini dilaksanakan secara virtual menggunakan media zoom dan video youtube. Jumlah masyarakat yang terlibat sebagai sasaran dalam kegiatan pengabdian kepada masyarakat ini adalah 32 orang. Kegiatan ini dilakukan dengan metode diskusi interaktif dan pelatihan menggunakan video demontrasi yang dapat diakses di youtube. Proses pembuatan serbuk sari buah dilakukan dengan menggunakan teknik kristalisasi dengan formula dan prosedur yang disederhanakan sehingga peserta dan masyarakat uтит mudah untuk mempelajarinya. Hasil kegiatan pelatihan menunjukkan adanya peningkatan skor pengetahuan peserta setelah mengikuti pelatihan sebanyak rata-rata $10 \%$ untuk setiap aspek dan peserta mampu membuat sendiri minuman serbuk sari buah. Setalah kegiatan pengabdian ini dilakukan peserta sangat puas dan berniat untuk melakukan usaha pengolahan minuman serbuk untuk dapat meningkatkan pendapatan.

Kata kunci: Minuman; Serbuk; Sari Buah; Kristalisasi

\begin{abstract}
Generally, during the Covid-19 pandemic, community's incomes decreased. This activity aims to improve the community knowledge and skills of Benda Baru, Pamulang District, South Tangerang in processing fruit juice powder drinks. Fruits were the perishable foods and have a very cheap price when the harvest was abundant. This activity was carried out virtually using zoom media and youtube videos. The community targets in these activities were 32 participants. This activity was carried out using interactive discussion methods and training using demonstration videos which colud be accessed on YouTube. The process of making fruit juice powder drinks was carried out using crystallization techniques with simplified formulas and modified procedures in order that participants were easy to learn. The results of the training showed an increase of the knowledge score of the participants by an average of $10 \%$ for each aspect. The participants were able to make fruit juice powder drink. After this service activity was carried out, the participants were very satisfied and they intended to produced fruit juice powder drink to increase their income.
\end{abstract}

Keywords: Drinks; Powder; Fruit Juice; Crystallization 
Ridawati, Alsuhendra

Pelatihan Pembuatan Minuman Serbuk Sari Buah untuk Meningkatkan Pengetahuan dan Ketrampilan

Masyarakat

\section{PENDAHULUAN}

Pandemi Covid-19 di Indonesia berdampak pada kehidupan sosial ekonomi masyarakat. Banyak perubahan terjadi pada kehidupan manusia, mulai dari berbagai kegiatan sehari-hari seperti belajar, kuliah, pelatihan, bekerja, serta pola aktivitas masyarakat lainnya. Adanya pembatasan sosial berskala besar (psbb) untuk mencegah penularan virus ini menyebabkan terhambat dan menurunnya pendapatan masyarakat secara umum. Kebijakan psbb telah menurunkan secara drastis aktivitas dan pergerakan orang di Jabodetabek dan kota-kota besar di Indonesia (Hadiwardoyo, 2020).

Dalam rangka meningkatkan keadaan perekonomian keluarga, dan perbaikan kondisi masyarakat, pemerintah Indonesia terus melakukan berbagai upaya dan modifikasi berbagai kegiatan agar tetap bisa terlaksana dengan baik. Berbagai usaha untuk mengatasi permasalahan ekonomi yang dihadapi, antara lain melalui pengembangan usaha dan kegiatan pendidikan pelatihan pembinaan ketrampilan hidup sehingga dapat berkembang usaha mikro dimasyarakat. Kegiatan-kegiatan bersifat informal yang dilakukan setiap lapisan masyarakat diharapkan dapat meningkatkan taraf hidup dan memperbaiki keadaan ekonomi masyarakat saat ini. Seperti dilaporkan bahwa Pendidikan non formal dapat meningkatkan pengetahuan dan ketrampilan (Hatimah, 2016; A. Hidayat et al., 2017).

Pelatihan pembinaan ketrampilan hidup memiliki peranan yang sangat penting karena konsep salah satunya untuk meningkatkan kualitas sumber daya manusia (Tampongangoy, 2018), Pelatihan pembinaan ketrampilan hidup dimulai sejak pendidikan dasar (Krismiyati, 2017). Kualitas sumber daya manusia yang memiliki ketrampilan dapat digunakan untuk melakukan usaha dan menghasilkan pendapatan (D. Hidayat, 2013; Subagja dan Rosita, 2019) Hal ini berguna untuk meningkatkan produktivitas masyarakat.

Beranekaragam buah-buahan tumbuh tersebar di berbagai wilayah di Indonesia (Komarayanti, 2017; Zurriyati dan Dahono
, 2016). Buah-buahan yang tumbuh di Indonesia dan ditanam oleh penduduk Indonesia dinamakan buah lokal. Buah memiliki kandungan gizi, vitamin, mineral dan serat yang sangat perlu untuk dikonsumsi setiap hari (Rantika dan Rusdiana, 2018). Keanekaragaman warna pada buah juga sangat bervariasi. Warna buah merupakan gambaran tentang nutrisi buah. Buah banyak mengandung senyawa antioksidan dan senyawa fitokimia lainnya (Febrianti et al., 2015). Sebagai contoh adalah buah mangga yang memiliki warna kuning oranye menggambarkan vitamin yang terkandung didalam daging buah ini (Agustini dan gafar, 2018).

Buah unggulan nasional yang peluang pasarnya terbuka adalah jeruk, pisang, pepaya, mangga, durian, manggis, sawo, apokat, melon, dan semangka. Keragaman dan kekayaan buah local sangat berlimpah (Hermanto et al., 2013; Zurriyati \& Dahono., 2016). Suatu jenis buah disebut unggul apabila memiliki produktivitas buah per pohon dalam suatu musim panen lebih besar daripada buah sejenis, berproduksi pada umur relatif muda, tahan terhadap hama dan penyakit, kelezatan (rasa) dan aroma buah, dan keseragaman bentuk, ukuran, dan warna buah (Soepono, 2001).

Kristalisasi merupakan istilah yang menunjukkan beberapa fenomena yang berbeda berkaitan dengan pembentukan struktur kristal (Haryanto, 2018). Empat tahap pada proses kristalisasi meliputi pembentukan kondisi lewat jenuh atau lewat dingin, nukleasi atau pembentukan kristal inti kristal, pertumbuhan kristal, dan rekristalisasi atau pengaturan kembali struktur kristalin sampai mencapai energi terendah. Ketika suatu cairan atau larutan telah jenuh, terdapat termodinamika yang mendorong kristalisasi. Molekul-molekul cenderung membentuk kristal karena pada bentuk kristal, energi sistem mencapai minimum. Selama nukleasi atau pembentukan inti kristal, molekul dalam wujud cair mengatur diri kembali dan membentuk klaster yg stabil dan mengorganisasikan diri membentuk matriks kristal. Pertumbuhan kristal berlanjut sampai semua molekul membentuk kristal dan sistem mencapai kesetimbangan. Ketika kesetimbangan telah tercapai, perubahan masih 
Ridawati, Alsuhendra

Pelatihan Pembuatan Minuman Serbuk Sari Buah untuk Meningkatkan Pengetahuan dan Ketrampilan

Masyarakat

tetap dapat terjadi pada struktur kristalin selama penyimpanan dalam waktu lama

Pembuatan minuman serbuk rempah rempah telah banyak dilakukan masyarakat diantaranya minuman serbuk jahe (Sukmawati dan Merina, 2019). Kegiatan ini mengangkat tema pembuatan minuman serbuk sari buah. Minuman serbuk sari buah merupakan produk asli dari sari buah yang terdiri dari banyak pilihan jenis buah dan gula pasir. Minuman sari buah sangat cocok diminum sehari-hari dan dapat dikombinasikan dengan bahan lainnya seperti rempah, jeli, cincau, lidah buaya dan bahan lainnya (Geri et al., 2019; Susanti, 2016).

Dengan berubahnya pola konsumsi masyarakat kepada bahan alami dan ditambah dengan tingginya permintaan masyarakat akan minuman kesehatan dengan bahan-bahan alami yang tidak menimbulkan efek samping yang membahayakan, maka bisnis minuman serbuk menemukan momentum yang tepat untuk dikembangkan (Mdp, 1978; Sukmawati \& Merina, 2019). Bisnis minuman adalah salah satu bisnis yang mempunyai daya resistensi tinggi terhadap fluktuasi perekonomian (Gunawan, 2014). Dengan kondisi konsumen seperti ini maka pelatihan minuman sari buah serbuk adalah pilihan yang tepat.

Dengan khasiat yang banyak dan harga jual yang sangat terjangkau, maka tentunya pelatihan pembuatan minuman serbuk sari buah ini sangat potensial untuk dilakukan. Oleh karena itu kami tim pengabdian pada masyarakat Fakultas Teknik, Program Studi melakukan kegiatan pengabdian kepada masyarakat pelatihan pembuatan minuman serbuk sari buah dalam kemasan Benda Baru, Pamulang, Tangerang Selatan.

Beberapa permasalahan mitra yang menjadi titik perhatian perlunya dilakukan kegiatan pengabdian kepada masyarakat untuk melakukan pembuatan serbuk sari buah dalam kemasan adalah sebagai kasus pandemi yang sedang berlangsung menurunkan pendapatan masyarakat secara umum, psbb menurunkan produktivitas sebagian besar warga, kurangnya pengetahuan tentang pengolahan produk minuman sari buah, perlunya peningkatan pemahaman masyarakat tentang peningkatan nilai tambah bahan melalui proses pengolahan pangan, tingginya permintaan untuk pelatihan lanjut pembuatan minuman serbuk, rendahnya pengetahuan masyarakat untuk pengemasan minuman serbuk.

Berdasarkan permasalahan mitra tersebut ditawarkan alternatif solusi untuk mengatasi berbagai permasalahan yang dihadapi oleh masyarakat mitra. Solusi yang ditawarkan adalah peningkatan pengetahuan masyarakat tentang sari buah dan serbuk sari buah, peningkatan keterampilan masyarakat dalam membuat produk olahan sari buah menjadi serbuk sari buah, eningkatan wawasan masyarakat untuk mengemas serbuk sari buah dan memodifikasi dengan bahan lainnya untuk dapat diproduksi dan dijadikan salah satu sumber usaha keluarga.

\section{METODE}

Serangkaian kegiatan dilakukan untuk mengatasi permasalahan mitra. Kegiatan tersebut adalah penyuluhan materi melalui media zoom yang bertujuan meningkatkan pengetahuan serta kesadaran, kegiatan difusi ipteks yaitu kegiatan yang menghasilkan produk minuman serbuk sari buah dengan teknik kristalisasi, kegiatan yang disertai dengan demonstrasi atau melalui video youtube untuk mendapatkan keterampilan membuat serbuk sari buah. Tertentu. Kegiatan-kegiatan dilakukan dalam bentuk kegiatan pengabdian kepada masyarakat.

Tempat pelaksanaan secara virtual zoom pada tanggal 1 September 2020 pukul 13.00 dan video youtube. Sasaran yang dilibatkan dalam kegiatan adalah 32 orang masyarakat Kelurahan Benda Baru dan sekitarnya. Bahan yang digunakan pada kegiatan ini adalah buah, gula pasir, dan air. Sementara itu, alat yang dibutuhkan adalah blender, kompor gas, wajan, sutil, baskom kecil, saringan kain, pisau, sendok, dan gelas. Tahap dari kegiatan ini ada 3, yaitu:

Pra-Kegiatan, pada tahap ini, kegiatan yang dilakukan adalah: 1) Mendata potensi lokal daerah tempat peserta pelatihan melalui media watsapp; 2) Pembuatan produk minuman serbuk sari buah; dan 3) Penyiapan materi pelatihan, perancangan label produk, dan pembuatan angket pre-test dan post-test. 4) 
Pembuatan video demontrasi dan upload video ke youtube.

Pelaksanaan Kegiatan, kegiatan dilaksanakan dalam bentuk diskusi tentang minuman serbuk sari buah, bahan baku, proses pembuatan dan peluang usaha. Kegiatan selanjutnya adalah demonstrasi pembuatan minuman serbuk sari buah dengan pemutaran video melalui zoom dan youtube. Evaluasi Hasil Kegiatan, evaluasi dilakukan dengan cara memberikan angket yang berisi pertanyaan tentang minuman serbuk sari buah kepada sasaran dalam bentuk pilihan ganda.

\section{HASIL DAN PEMBAHASAN}

Pembuatan video. Pengabdian pada Masyarakat dengan topik pembuatan minuman serbuk sari buah diawali dengan pembuatan video pelatihan. Video pelatihan pembuatan serbuk sari buah bersama-sama dengan mahasiswa D3 Tata Boga, Fakultas Teknik UNJ. Mahasiswa yang terlibat adalah mahasiswa tingkat akhir yang telah mengambil Mata Kuliah Teknologi Minuman.

Tahapan pekerjaan pembuatan video pelatihan ini adalah dimulai dari tahapan perencanaan, persiapan alat dan bahan, pengambilan gambar dan pengisian suara serta pengeditan. Tahapan perencanaan secara umum merupakan tahapan sebelum memulai proses pembuatan video. Tujuan perencanaan adalah mempersiapkan segala sesuatunya agar proses pembuatan video dapat berjalan sesuai konsep dan menghasilkan suatu karya digital video sesuai dengan harapan.

Pada tahap awal disusun ide atau gagasan atau rencana, skema atau metode atau alur cerita sebagai landasan utama dari keseluruhan proses pembuatan video tersebut. Selanjutnya ditentukan sasaran yang akan menonton video tersebut, pada pengabdian ini video ditujukan untuk masyarakat umum sebagai khalayak sasaran. Pokok materi video ini adalah tentang pembuatan minuman serbuk sari buah. Selanjutnya disusun naskah video yaitu suatu teks yang berisi aturan, alur cerita di dalam suatu dialog.

Naskah dalam pembuatan video proses kali ini dibuat agar presenter mengerti detail dari presentasi yang akan disampaikan.
Presenter pada video ini adalah tim pengabdian pada masyarakat tentang pembuatan serbuk sari buah, secara bergantian untuk setiap sesi. Naskah yang disusun ditungkan ke dalam storyboard. Storyboard adalah serangkaian sketsa dibuat berbentuk persegi panjang yang menggambarkan suatu urutan yang diusulkan untuk menjadi panduan dalam proses perekaman, pengambilan gambar dan pengisian suara. Pengambilan gambar pada pembuatan video ini dilakukan dengan proses sederhana memanfaatkan pencahayaan alami yaitu cahaya matahari, dimana presenter harus menghadap sumber cahaya utama.

Setelah proses pengambilan gambar selesai dilakukan proses pengisian suara dan pengeditan video. Video yang sudah selesai siap diunggah ke youtube dan dipresentasikan pada saat webinar melalui media zoom.

\section{Sosialisasi kegiatan dan Pendataan Peserta \\ Pelatihan. Perekrutan peserta dilakukan} melalui kontak via sosial media dan watsapp group yang dibuat oleh tim. Koordinasi, pelaksanaan pra pelatihan, pasca pelatihan juga dilakukan melalui media wa grup ini. Koordinasi awal yaitu pemberian link media zoom dan link pengisian presensi kehadiran serta pengisian pretest. Selanjutkan ketika pelaksanaan kegiatan diberikan juga link untuk melihat video di youtube. rentang umur ini mengacu pada pengelompokkan rentang umur (Hurlock, 2006). Masa dewasa awal dimulai pada umur 18-40 tahun, masa dewasa madya dimulai pada umur 40 - 60 tahun, yakni saat baik menurunnya kemampuan fisik dan psikologis yang jelas nampak pada setiap orang, masa dewasa lanjut (umur lanjut) dimulai pada umur 60 tahun sampai kematian. Peserta pelatihan ini sebagian besar $(50 \%)$ adalah orang yang berada pada masa dewasa madya (Gambar 1). Peserta menyadari kebutuhannya untuk mencari pengetahuan dan ketrampilan yang lebih luas untuk mendukung ekonomi keluarga, meningkatkan kesehatan dan dapat dijadikan peluang usaha.

Berbagai jenis pekerjaan peserta pelatihan dapat dilihat pada Gambar 2 . Sebanyak $41 \%$ peserta adalah ibu rumah tangga, $22 \%$ karyawan swasta, $16 \%$ mahasiswa, $9 \%$ aparatur sipil negara dan $6 \%$ 
pensiunan. Sebaran pekerjaan peserta pelatihan menunjukkan bahwa peserta sebagian besar adalah ibu rumahtangga yang memang memiliki banyak peluang untuk melakukan berbagai jenis kegiatan di usia dewasa madya, karena sudah tidak disibukkan lagi oleh urusan rumahtangga.

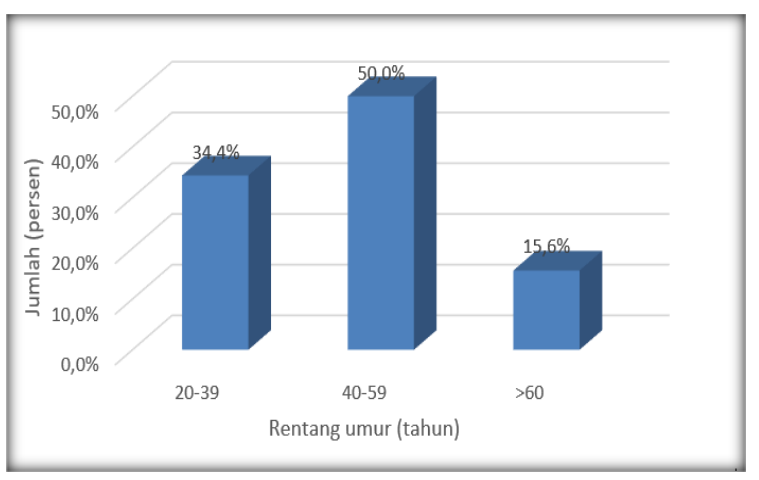

Gambar 1. Sebaran Umur Peserta Pelatihan Pengabdian pada Masyarakat

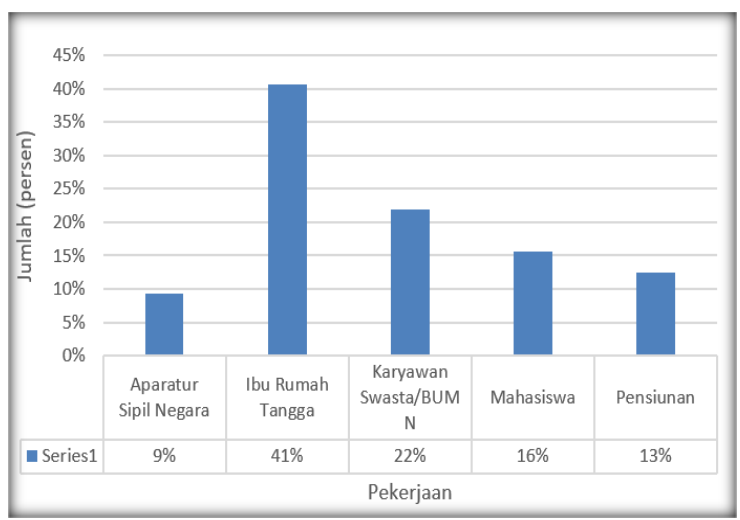

Gambar 2. Jenis Pekerjaan Peserta Pelatihan

Penyampaian materi oleh tim narasumber kepada masyarakat sasaran, agar sasaran dapat mengetahui materi tentang bahan dan produk yang akan dibuat melalui media zoom (Gambar 3). Melalui penyampaian materi ini, narasumber memberikan informasi tentang buah-buahan, dan peluang untuk menjadikan minuman serbuk sari buah sebagai alternatif usaha rumah tangga.

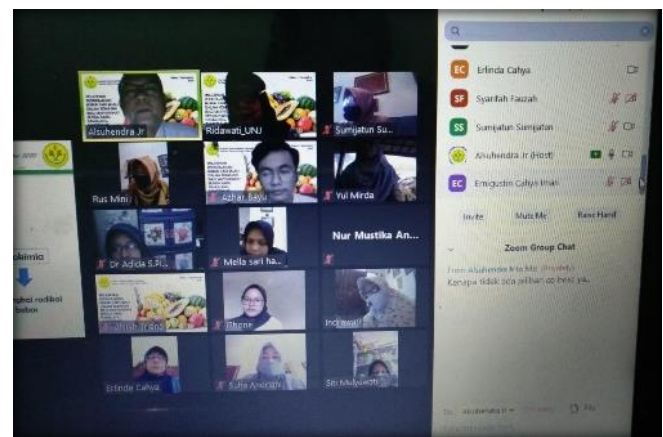

Gambar 3. Kegiatan Pelaksanaa Pelatihan melalui media zoom

Sebelum kegiatan penyampaian materi diajukan beberapa pertanyaan untuk mengetahui pengetahuan dasar dari peserta (pre-test). Selanjutnya dilakukan penyampaian materi, pemutaran video pelatihan, diskusi dan terakhir dilakukan post test.

Pertanyaan awal yang diajukan adalah pengetahuan umum tentang minuman serbuk, minat dan sikap terhadap minuman serbuk. Sebanyak $84 \%$ peserta belum pernah membuat minuman serbuk (Gambar 4).

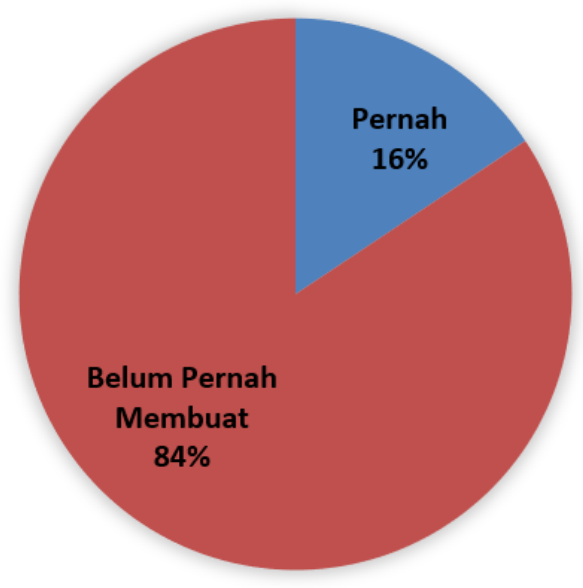

Gambar 4. Pernah atau tidaknya peserta membuat minuman serbuk

Sebanyak $87 \%$ peserta (Gambar 5) menyatakan meraka pernah mengonsumsi minuman serbuk. Minuman serbuk yang dikonsumsi peserta umumnya adalah minuman serbuk rempah seperti minuman serbuk jahe, jahe susu dan jahe merah. 


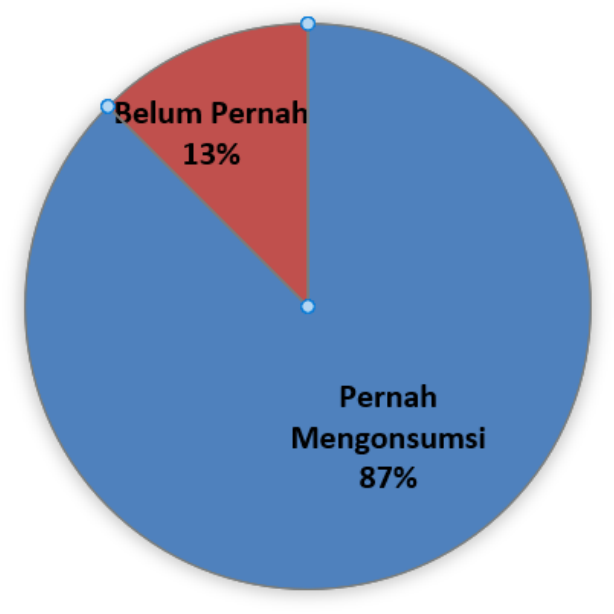

Gambar 5. Pernah atau tidaknya peserta mengonsumsi minuman serbuk

Tetapi sebenarnya peserta juga telah mengetahui adanya minuman serbuk sari buah (Gambar 6), walaupun sebagian berasumsi bahwa minuman serbuk rasa buah adalah minuman serbuk sari buah.

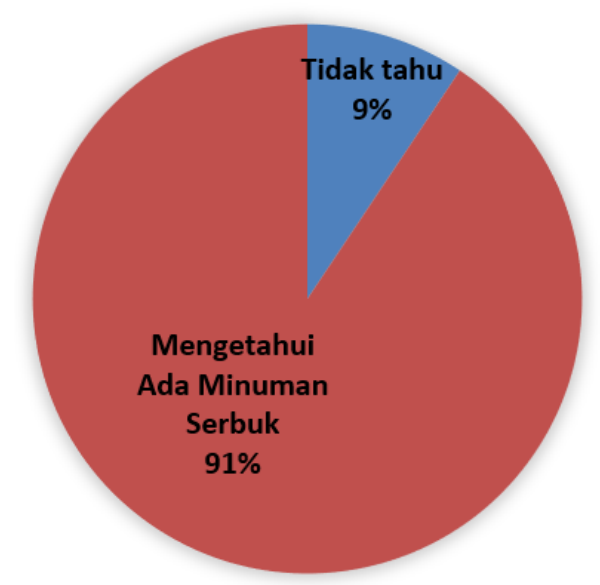

Gambar 6. Mengetahui adanya minuman serbuk

Seluruh peserta sangat berminat untuk mengikuti pelatihan dengan tujuan untuk meningkatkan pengetahuan dan ketrampilan mereka (Gambar 7). Minat para peserta terlihat dari antusias peserta untuk mengikuti proses pelatihan dan mendengarkan materi tentang buah-buahan, kandungan gizi buah, proses pengemasan dan proses pembuatan serbuk sari buah.

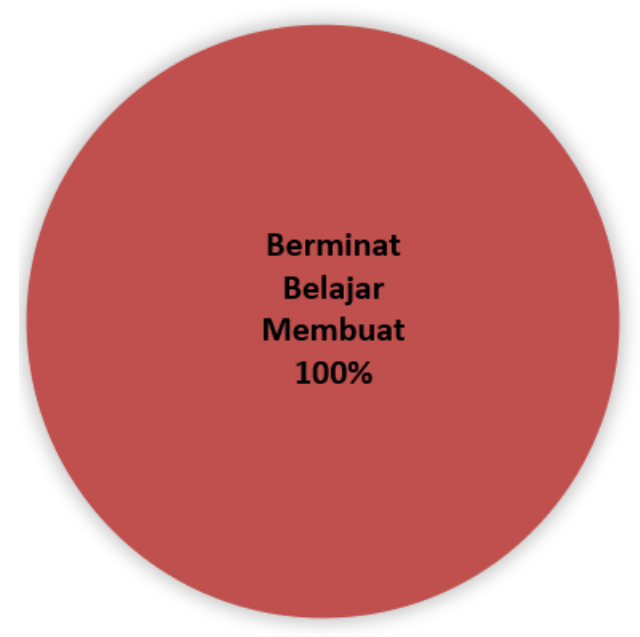

Gambar 7. Minat belajar membuat minuman serbuk

Pemberian materi dilakukan melalui media zoom dengan antusiasme peserta. Beberapa peserta yang tidak dapat hadir melalui zoom, mengikuti kegiatan pelatihan pembuatan minuman serbuk melalui video yang ditayangkan di youtube dengan link : https://www.youtube.com/channel/UCelNzr1G XlEYfZ_Z7fDdtoQ. Video pelatihan berdurasi 11 menit 51 detik memaparkan proses pembuatan minuman serbuk dari sari buah manga, jambu biji dan buah naga. Serta diberikan juga proses pembuatan serbuk sari secang sebagai bahan yang dapat digunakan untuk campuran serbuk buah agar memiliki warna yang lebih menarik.

Pada kegiatan pelatihan melalui zoom diberikan materi tentang buah, kandungan gizi buah. Buah-buahan mengandung zat gizi seperti vitamin dan zat non gizi seperti serat makanan (Rantika dan Rusdiana, 2018). Buahbuahan juga mengandung senyawa fitokimia yang dapat menangkal radikal bebas (Febrianti et al., 2015). Diterangkan juga bahwa radikal bebas adalah atom atau molekul yang memiliki elektron tidak berpasangan, bersifat sangat labil karena mencari elektron yang hilang. Hasil pretest menunjukkan hanya $66 \%$ peserta yang menjawab dengan benar kandungan utama yang terdapat pada buah yaitu serat makanan (Gambar 8). Setelah pemaparan materi terjadi peningkatan sebanyak 14\% (Gambar 9). 


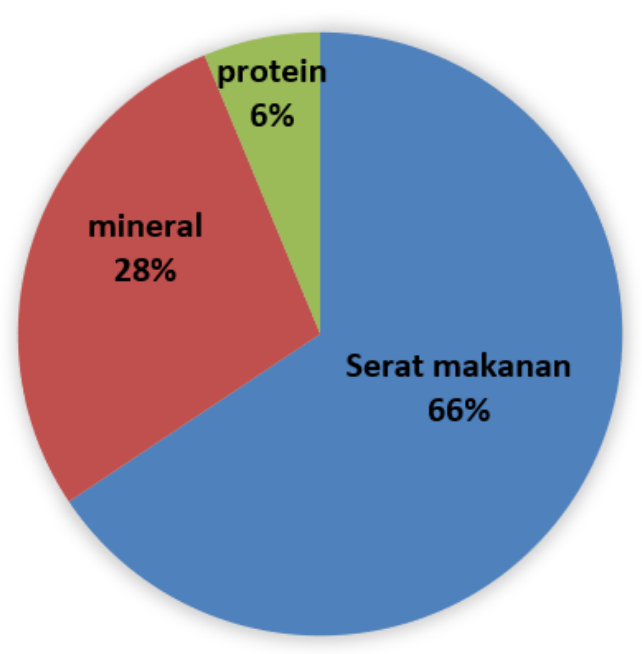

Gambar 8. Hasil pre-test tentang kandungan yang terdapat didalam buah

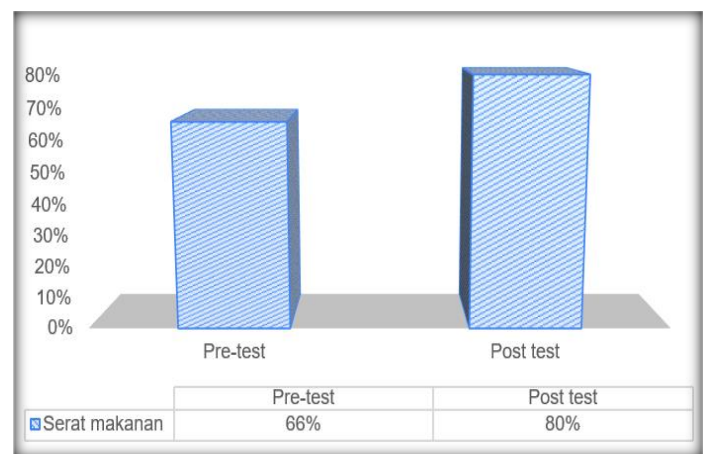

Gambar 9. Peningkatan pengetahuan peserta tentang kandungan serat pada buah

Selain mengandung serat, pada buah juga banyak terdapat senyawa fitokimia yang bersifat antioksidan. Sebelum pemaparan materi sebanyak $81 \%$ peserta sudah dapat menjawab dengan benar pertanyaan ini (Gambar 10). Iklan di media masa tentang antioksidan dapat dimengerti oleh masyarakat, termasuk peserta pelatihan. Setelah pemaparan materi terjadi peningkatan peserta yang menjawab menjadi 92\% (Gambar 11).

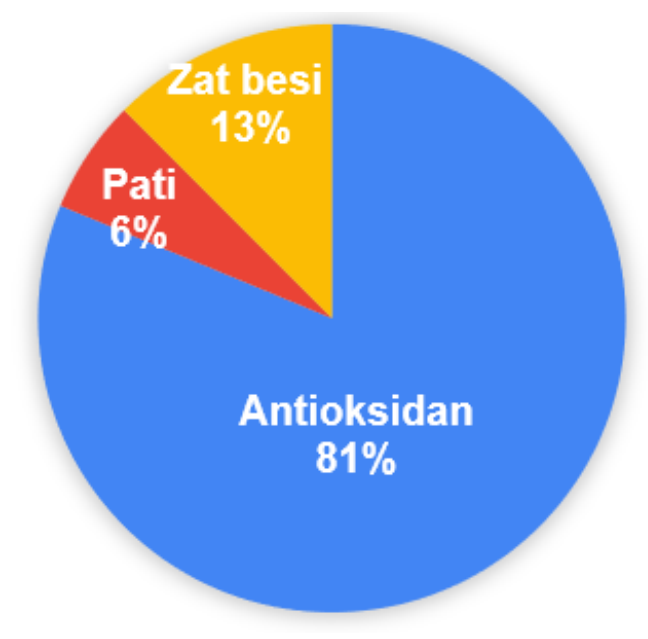

Gambar 10. Pengetahuan tentang adanya senyawa antioksidan pada buah

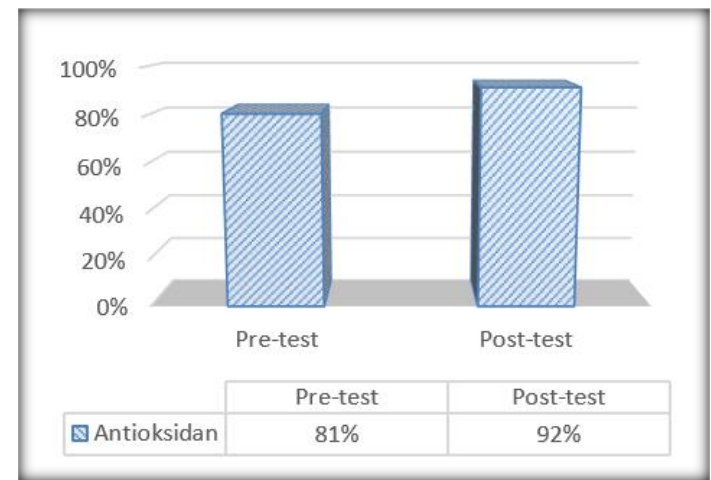

Gambar 11. Peningkatan pegetahuan tentang senyawa antioksidan pada buah

Hasil survey kepuasan peserta setelah mengikuti pelatihan ini menunjukkan seluruh peserta tertarik untuk membuat minuman sari buah serbuk, karena proses pengolahan yang tidak sulit dengan menggunakan bahan dan alat yang sederhana. Disamping itu menurut peserta produk yang dihasilkan layak untuk dijual, peserta dapat mengembangkan produk minuman serbuk lainnya sesuai dengan potensi bahan yang tersedia dan permintaan pasar.

Setelah kegiatan berakhir peserta masih dapat melihat video melalui link youtube yang dibagikan, sebagai panduan untuk berlatih. Sebagian besar peserta sangat antusias dan mengharapkan kegiatan pendampingan dapat dilakukan untuk pelatihan hingga dapat dilakukan produksi berkelanjutan.

Tim pengabdian juga memberikan contoh kemasan dan label yang dapat dikembangkan untuk proses pengemasan dan 
pelabelan produk yang dihasilkan peserta. Label dibuat berdasarkan aturan yang ditetapkan Badan Pengawasan Obat dan Makanan (Penyusun, 2019). Pada label dicantumkan nama jenis pangan olahan, merk dagang, komposisi, berat bersih, nama dan alamat produsen, tanggal kadaluarsa dan keterangan tambahan seperti cara penyajian (Gambar 12). Sebagai contoh diberikan label sari buah manga instan dengan merk dagang "Pamura", berat bersih 35 gram, komposisi sari buah manga dan gula pasir. Label selanjutnya ditempel pada bagian luar kemasan plastik. Penulisan komposisi pada label kemasan sangat penting. Komposisi dan label gizi merupakan suatu informasi kandungan gizi yang terkandung dalam produk pangan disertai jumlah kandungan tersebut dalam tiap sajian atau kemasan makanan. Seperti dilaporkan oleh peneliti lainnya bahwa penulisan komposisi gizi membantu konsumen untuk menghindari atau mengurangi kelebihan ataupun kekurangan asupan zat gizi yang dapat berakibat pada masalah kesehatan terkait pola makan (Palupi et al., 2017). Produk dengan label dalam kemasan dapat dilihat pada Gambar 13.

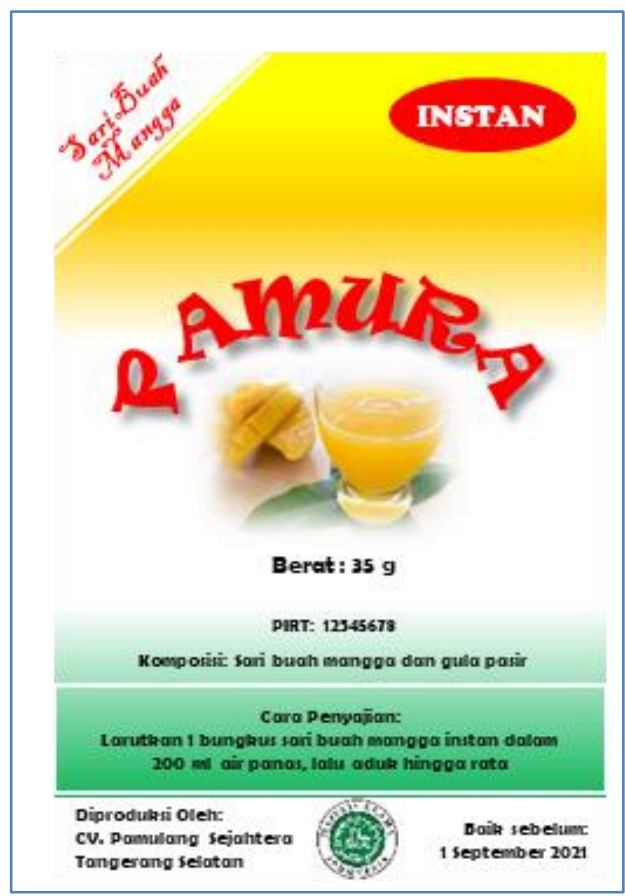

Gambar 12. Label minuman serbuk sari buah manga

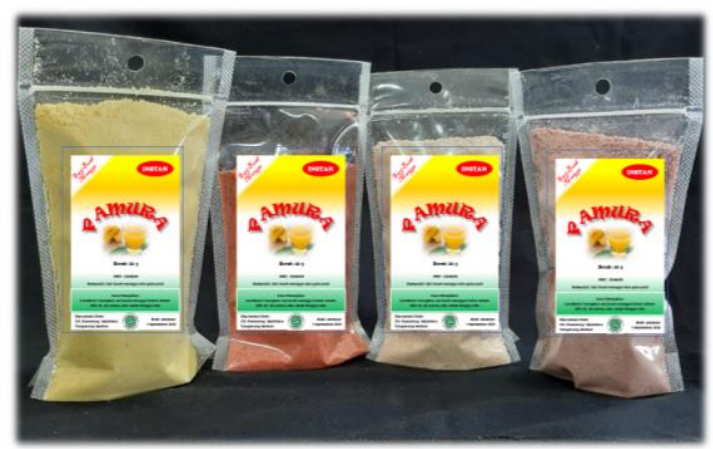

Gambar 13. Produk Minuman Serbuk Sari Buah dalam Kemasan

Tim pengabdian kepada masyarakat telah dapat melaksanakan kegiatan pengabdian bagi masyarakat Kelurahan Benda Baru dan sekitarnya dengan lancar. Tingkat pengetahuan sasaran menunjukkan adanya peningkatan setelah dilakukan kegiatan pemaparan materi dan diskusi melalui zoom antara peserta dan narasumber. Demikian juga sikap dan antusiasme peserta juga terlihat cukup baik karena sebagian besar mau mencoba untuk membuat produk minuman serbuk sari buah setelah mengikuti kegiatan ini.

\section{SIMPULAN}

Kesimpulan yang dapat diambil dari kegiatan pelatihan ini adalah kegiatan pelatihan melalui media zoom dan youtube tentang pembuatan minuman serbuk sari buah bagi masyarakat dapat meningkatkan pengetahuan sasaran dalam mengolah sari buah menjadi minuman serbuk. Peserta memiliki sikap yang antusias dalam mengikuti seluruh tahap kegiatan dan dapat mengakses video youtube yang diberikan. Seluruh peserta mengikuti kegiatan pengabdian kepada masyarakat ini dengan tujuan untuk mendapatkan pengetahuan dan keterampilan yang dapat dijadikan modal usaha untuk dapat meningkatkan pendapatan.

\section{DAFTAR PUSTAKA}

Agustini, S., \& gafar, patoni. (2018). Pengembangan Produk Bubuk Buah Mangga the Production of Mango ( Mangifera Indica L ) Powder. Pengembangan Produk Bubuk Buah Mangga (Mangifera Indica L) Instan, 29(1), 66-73. 
Febrianti, N., Yunianto, I., \& Dhaniaputri, R. (2015). Kandungan Antioksi dan Asam Askorbat pada Jus Buah-Buahan Tropis. Jurnal Bioedukatika, 3(1), 6. https://doi.org/10.26555/bioedukatika.v3i 1.4130

Geri, J. D., Ayu, D. F., \& Harun, N. (2019). Kombinasi Minuman Lidah Buaya Berkarbonasi dengan Sari Lemon Combination of Carbonated Aloe Vera Drink with Lemon Juice Jefrianta Demu Geri 1 , Dewi Fortuna Ayu. Jurnal Agroindustri Halal, 5(2), 132-140.

Gunawan, M. Y. (2014). Business plan rosella and fruit juice UD. laberry. Ilmiah Maahasiswa Universitas Surabaya, 3(1), $1-33$.

Hadiwardoyo, W. (2020). Kerugian Ekonomi Nasional Akibat Pandemi Covid-19. Baskara Journal of Business and Enterpreneurship, 2(2), 83-92. https://doi.org/10.24853/baskara.2.2.8392

Haryanto, B. (2018). Pengaruh Penambahan Gula Terhadap Karakteristik Bubuk Instan Daun Sirsak (Annona Muricata L.) Dengan Metode Kristalisasi. Jurnal Penelitian Pascapanen Pertanian, 14(3), 163.

https://doi.org/10.21082/jpasca.v14n3.20 $17.163-170$

Hatimah, I. (2016). Regulasi Dan Implementasi Pendidikan Informal. PEDAGOGIA Jurnal Ilmu Pendidikan, 13(1), 194. https://doi.org/10.17509/pedagogia.v13i1 .3387

Hermanto, C., Luh, N., Indriani, P., \& Hadiati, S. (2013). Keragaman dan Kekayaan Buah Tropika Nusantara. Badan Penelitian Dan Pengembangan Pertanian Kementerian Pertanian, 68-70.

Hidayat, A., Anwar, A., \& Hidayah, N. (2017). Pendidikan Non Formal. Jurnal Edudeena, 1(1), 31-42.

Hidayat, D. (2013). Dampak Pelatihan Keterampilan Hidup ( Life Skills ) Montir Otomotif Terhadap Kesempatan Kerja the
Impact of Life Skill Training for Automotive Mechanic in Employment Opportunity and Learners ' Income. Jurnal Ilmiah VISI PPTK PAUDNI, 11(2), 81-98.

Hurlock, E. B. (2006). Psikologi Perkembangan. Book, 2006.

Komarayanti, S. (2017). Ensiklopedia Buahbuahan Lokal Berbasis Potensi Alam Jember Encyclopedia Of Local Fruits Based On Natural Potential Jember. Jurnal Biologi Dan Pembelajaran Biologi, 2(1), 61-75.

Krismiyati, K. (2017). Pengembangan Sumber Daya Manusia dalam Meningkatkan Kualitas Pendidikan di SD Negeri Inpres Angkasa Biak. Jurnal Office, 3(1), 43. https://doi.org/10.26858/jo.v3i1.3459

Mdp, S. (1978). Fruit N Vege Juice (Perencanaan Pendirian Usaha Jus Buah dan Sayur). $x$.

Palupi, I. R., Naomi, N. D., \& Susilo, J. (2017). Penggunaan Label Gizi dan Konsumsi Makanan Kemasan pada Anggota Persatuan Diabetisi Indonesia. Kes Mas: Jurnal Fakultas Kesehatan Masyarakat, 11(1), 1-8. https://doi.org/10.12928/kesmas.v11i1.20 65

Penyusun, T. I. M. (2019). Label Pangan Olahan. E-Book Panduan Registrasi Pangan Olahan Badan Pengawasan Obat Dan Makanan.

Rantika, N., \& Rusdiana, T. (2018). Artikel Tinjauan: Penggunaan Dan Pengembangan Dietary Fiber. Farmaka, 16, 152-165.

Soepono,

P.

(2001).

Kajian_Pengembangan_Komoditas_Ung gulan_Buah-Buahan. Jurnal Ekonomi Dan Bisnis Indonesia, 16(1), 41-53.

Subagja, A., \& Rosita, T. (2019). Upaya Peningkatan Pendapatan Masyarakat melalui Program Pelatihan Tata Kecantikan Rambut. Jurnal Comm-Edu, 2(2), 133-141. 
Ridawati, Alsuhendra

Pelatihan Pembuatan Minuman Serbuk Sari Buah untuk Meningkatkan Pengetahuan dan Ketrampilan Masyarakat

Sukmawati, W., \& Merina, M. (2019).

Pelatihan Pembuatan Mipelatihan

Pembuatan Minuman Herbal Instan

Untuk Meningkatkan Ekonomi

Warganuman Herbal Instan Untuk

Meningkatkan Ekonomi Warga. Jurnal

Pengabdian Kepada Masyarakat, 25(4),

210.

https://doi.org/10.24114/jpkm.v25i4.148

74

Susanti, C. (2016). Pengaruh Perbandingan Sari

Buah Naga Merah ( Hylocereus polyrhizus ) Dengan Sari Buah Salak

Bongkok ( Salacca edulis Reinw ) Dan Jenis Penstabil Terhadap Karakteristik Sirup Buah. Artikel Sirup Buah Dari Campuran Sari Buah Naga Merah Dan Sari Buah Salak Bongkok, 1-18.

Tampongangoy, D. L. (2018). Kualitas Sumber Daya Manusia Dalam Meningkatkan Pembangunan Desa Tinggilbet Distrilk Beoga Kabupaten Puncak Provinsi Papua. Jurnal Administrasi Publik, 4(58).

Zurriyati, Y., \& Dahono. (2016). Keragaman Sumber Daya Genetik Tanaman BuahBuahan Eksotik di kabupaten Bintan, Provinsi Kepulauan Riau. Buletin Plasma Nutfah, 22(1), 11-20. 